\title{
Sound Absorption Performance of Sugar Palm Trunk Fibers
}

\author{
Anditya Endar Prabowo ${ }^{1}$, Kuncoro Diharjo ${ }^{1, *}$, Ubaidillah $^{1}$, and Iwan Prasetiyo ${ }^{2}$ \\ ${ }^{1}$ Mechanical Engineering Department, Engineering Faculty, Sebelas Maret University, \\ J1. Ir Sutami No.36 A, Surakarta 57126, Indonesia \\ ${ }^{2}$ Acoustic Laboratory, Engineering Physics Department, Bandung Institute of Technology, \\ Jl. Ganesha No.10, Bandung 40116, Indonesia
}

\begin{abstract}
The purpose of this research is to investigate the effect of bulk density, thickness, and air gap to sound absorption performance on absorber based sugar palm trunk fibers. The fibers were obtained from solid waste on Small-Medium Enterprises of sago flour processing in Klaten, Central Java, Indonesia. The absorber specimens were formed from the fibers using a simple press molding in an oven at $150{ }^{\circ} \mathrm{C}$. According to ISO 10534-2, the absorber samples were tested using two microphones impedance tube with random noise source to get the curve of the sound absorption coefficient. The result shows that the absorption performance can be improved by increasing bulk density and increasing of sample thickness. Especially at low frequencies, improvement of the sound absorption coefficient can be achieved (NAC $>0.8$ ) by applying the air gap behind the sample. The best performance of absorber based sugar palm trunk fiber can be achieved for (1 000 to 6000$) \mathrm{Hz}$ range frequency.
\end{abstract}

Key words: Acoustic material, natural fibers, sound absorption coefficient.

\section{Introduction}

\subsection{Sound absorbers from natural materials}

Noise pollution causes adverse effects on human health, i.e. bad emotions, sleep disturbances which cause daytime drowsiness, increase the risk of high blood pressure, cardiovascular disease and deafness which may be experienced by people who work in noisy environments [1]. Therefore, to meet human health needs, environmentally friendly acoustic materials are required to solve air pollution problems. In general, the sound absorber is grouped into three types, i.e. porous absorber, membrane absorber, and volume absorber [2]. While porous absorber can be categorized into three types, i.e. cellular, fibrous, and granular [3]. Fibrous is one type of absorber whose widely used. Fibrous type absorber is used in many areas including architecture, automotive industry and audio equipment [4]. The reasons for the use of fiber material are an economic factor and excellent sound absorption performance. Examples of fiber-based absorbers including

${ }^{*}$ Corresponding author: kuncorodiharjo@,ft.uns.ac.id 
natural material groups such as cotton (Gossypium arboretum L.) [5, 6], sugarcane (Saccharum officinarum L.) [7], wood [8], tea-leaf-fiber (Camellia sinensis L.) [9], rice straw (Oryza sativa L.) [10, 11], kapok (Ceiba pentandra L.) [4]; synthetic material group such as glass woll [12], polyacrylonitrile [13] and polyester [14]. Synthetic fibers have negative impacts including production processes which require large amounts of energy, causing high global warming potential $[15,16]$ and air pollution which irritates on eyes and skin, also cause pulmonary disease [17]. Therefore, research on natural materials is interesting research to seek alternative "green" and sustainable acoustic absorber.

\subsection{Previous studies on natural fibers}

Lim et al. [18] studied the absorption performance of kenaf fiber (Hibiscus cannabinus L.) and they found that the absorption coefficient of the fibers increased along with an increase of bulk density and thickness. For the thickness of $75 \mathrm{~mm}$, the absorption coefficient reached a maximum value of 1.0 at $1100 \mathrm{~Hz}$. Putra et al. [11] studied the acoustic performance of biomass made from rice straw and absorption coefficient reaches an average value of 0.8 above $2.5 \mathrm{kHz}$. An increase in the absorption coefficient can be achieved by adding a polyester fabric to the surface. Or et al. [19] proposed noise control absorber made from oil palm (Elaeis guineensis Jacq.) empty fruit bunch fibers. The optimum absorption coefficient with values above 0.9 ranging from (1 000 to 1500$) \mathrm{Hz}$ is achieved by $50 \mathrm{~mm}$ thick sample with a bulk density of $292.3 \mathrm{~kg} \mathrm{~m}^{-3}$. Xiang et al. [4] investigated sound absorption performance in kapok fibers. This study shows that kapok fibers have acoustic performance similar to glass woll. Moreover, kapok absorber produces a better performance at lower bulk density. Putra et al. [7] studied sugarcane waste fibers and found that sugarcane absorber with a thickness of 0.5 inches has equivalent performance to commercial synthetic fibers with the absorption of 0.65 at (1.2 to 4.5$) \mathrm{kHz}$. Putra et al. [20] proposed noise control absorber made from extracted PALF (pineapple-leaf fibers (Ananas comosus (L.) Merr.). PALF has an average sound absorption coefficient 0.9 at above $2000 \mathrm{~Hz}$ at $20 \mathrm{~mm}$ thickness, while the sample with $30 \mathrm{~mm}$ thick has an average absorption coefficient of 0.8 at above $1000 \mathrm{~Hz}$.

This paper discusses the potential of sugar palm (Arenga pinnata (Wurmb.) Merr.) trunk (SPT) fiber as a sound absorber based on natural, green and sustainable material. Conventionally, SPT fiber was used as food for worms [21] and mushroom growing media [22]. Until recently, early development of research has been done on palm sugar trunk fiber as raw material in glucose production [22], reinforcement in composite production [23, 24], and a raw material of briquette production [25]. As one of the waste in the flour processing industry with abundant quantity, SPT fiber also causes environmental problem [26]. Considering the potential of the SPT fiber, this paper contributes to the enrichment of acoustic materials and the opportunity to use SPT fiber as a commercial absorber and provide the resolution of solid waste in sago flour processing industries.

\section{Materials and experimental setup}

\subsection{Sample Fabrication}

The sugar palm trunk (SPT) fibers were obtained from Small-Medium Enterprises (SMEs) of sago flour processing in Klaten, Central Java, Indonesia. The SPT was processed using shredding machine to produced palm starch traditionally and it left solid waste containing fibers. On the SMEs area, the solid waste accumulates in many places and causes unhealthsmelling pollution. In the other hand, the fiber content in solid waste is quite high, which is 
around $50 \%$. These fibers were separated manually from the other materials. Then, the fibers were dried naturally and finally they were dried in an oven at $80{ }^{\circ} \mathrm{C}$ for $30 \mathrm{~min}$ to maximize the drying process. The fibers can be classified as hard fibers as shown in Figure 1.

Samples were made according to the standard size of the impedance tube measurement test. Fibers were weighed based on bulk density calculation and desired thickness. Then, the fibers were put into an aluminum mold with a diameter of $30 \mathrm{~mm}$. The forming process of samples was carried out in an oven under the temperature of $150{ }^{\circ} \mathrm{C}$ for $10 \mathrm{~min}$. Bulk density was obtained from fibers mass divided by sample volume. Table 1 shows the variation of sample mass, bulk density, and thickness.

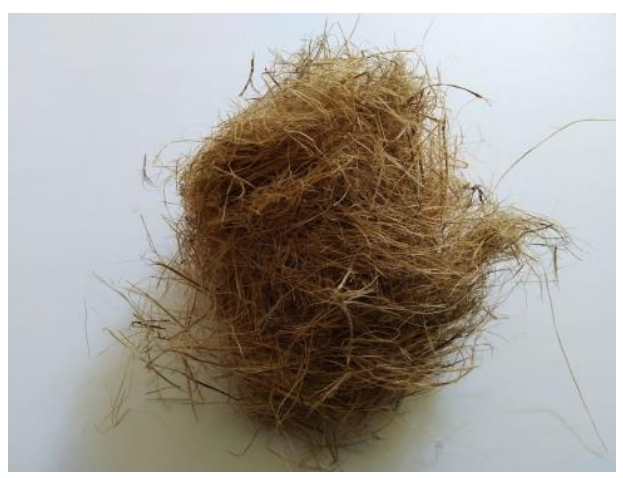

(a)

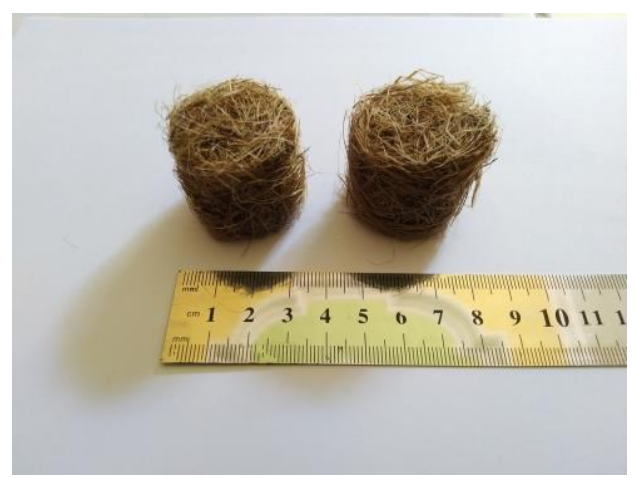

(b)

Fig. 1. (a) Raw SPT fiber, (b) Example of SPT fiber absorber.

Table 1. The variation of SPT fiber samples.

\begin{tabular}{|c|c|c|}
\hline $\begin{array}{c}\text { Mass of sample, } \\
\mathbf{m}(\mathbf{g})\end{array}$ & $\begin{array}{c}\text { Bulk density, } \\
\boldsymbol{\rho}_{\text {bulk, }} \mathbf{k g ~ m}^{\mathbf{- 3}}\end{array}$ & $\begin{array}{c}\text { Thickness of sample, } \\
\mathbf{t}(\mathbf{m m})\end{array}$ \\
\hline 1.5 & 70707 & 30 \\
\hline 2 & 94276 & 30 \\
\hline 2.5 & 117845 & 30 \\
\hline 3 & 141414 & 30 \\
\hline 4 & 141414 & 40 \\
\hline 5 & 141414 & 50 \\
\hline
\end{tabular}

\subsection{Experimental setup}

The measurement of sound absorption coefficient was done according to ISO 10534-2 test standard [26]. The configuration of the sample on the tube as shown in Figure 2. The sample was located at the end of the tube while at the other end mounted two microphones to record the sound. Before the microphones measurement was used, they had to be calibrated first using calibrator CA115 calibrator. The sound was produced by a sound generator. The analyzer was used to process the recorded signal to get the transfer function between two microphones. Then the software BSWA VA-Lab4 basic was used to calculate the sound absorption coefficient. 
The measurements were operated in the frequency range of (1 000 to 6000$) \mathrm{Hz}$. In this research, the frequency of ( 1000 to 2000$) \mathrm{Hz}$ was referred to as mid frequency, while the frequency of (2 000 to 6000$) \mathrm{Hz}$ was categorized as high frequency. This experiment varied on bulk density, thickness, and application of air gap behind the sample. All measurements were performed three times in each sample.

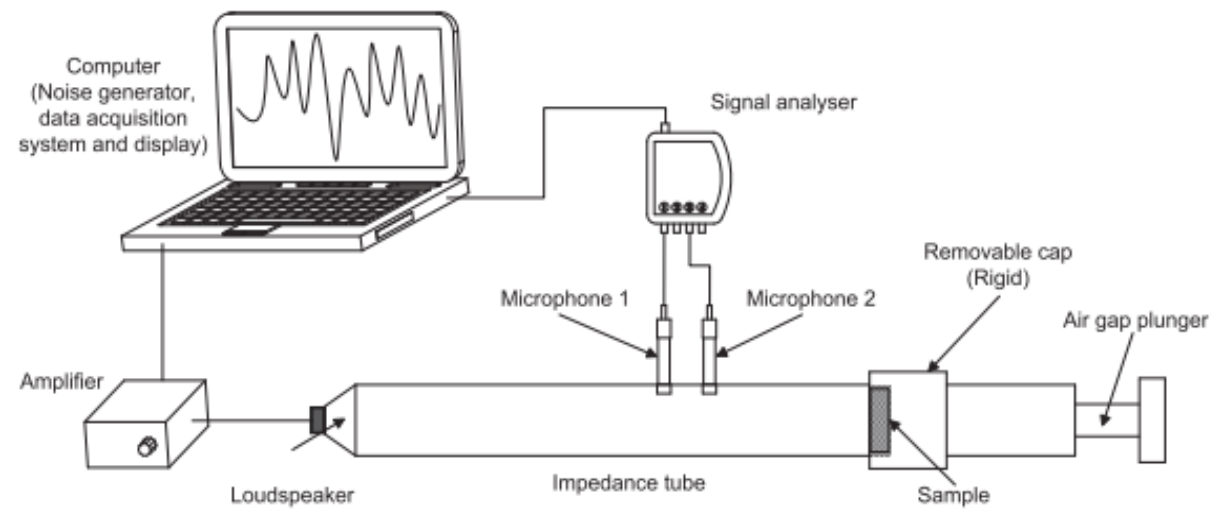

Fig. 2. Measurement setup for the sound absorption test.

\section{Results and discussions}

\subsection{Effect of bulk density}

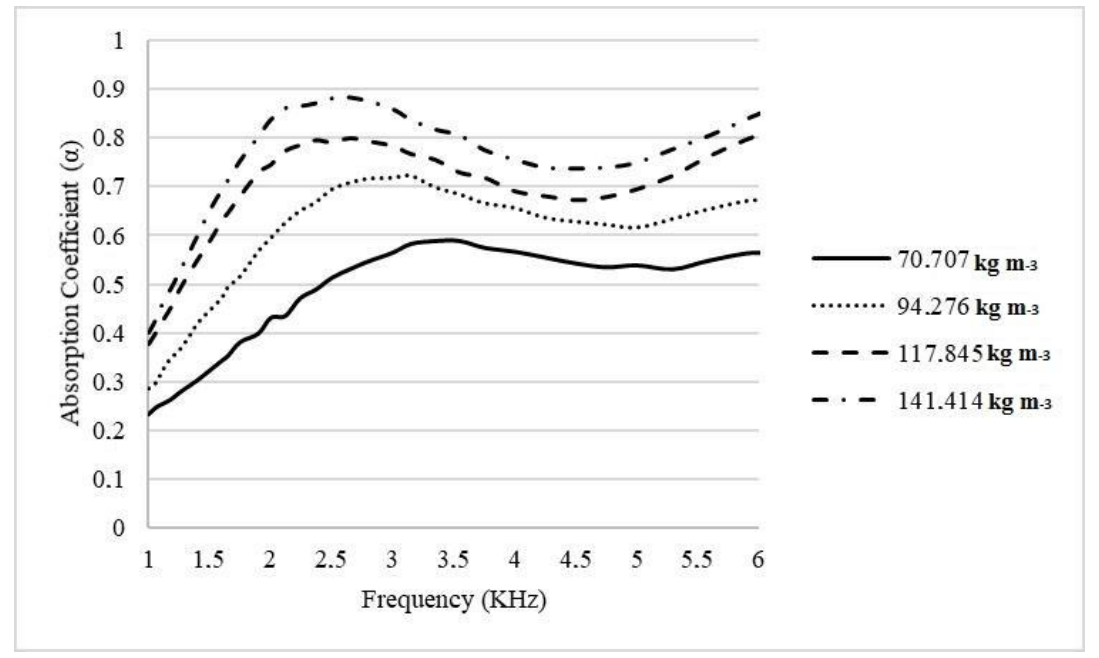

Fig. 3. Sound absorption coefficient of SPT fibers with different bulk density, pbulk with constant thicknesses, $\mathrm{t}=30 \mathrm{~mm}$.

The result of sound absorption coefficient measurement on different bulk density at a fixed $30 \mathrm{~mm}$ thickness is shown in Figure 3. At the same thickness, it shows that higher bulk density, higher sound absorption coefficient. The improvement is obvious from mid to high-frequency range. An increase in bulk density causes an increase in flow resistivity and tortuosity [20]. The high flow resistivity enhances the difficulty level of sound waves through fibers, so more energy will be lost due to friction between sound waves and fibers. 
While high tortuosity shows the level of complexity of fibers configuration in the sample. It causes more trapped sound waves and more absorbed sound waves.

\subsection{Effect of thickness}

The result of the sound absorption coefficient measurement varied in thickness is shown in Figure 4. In this result, samples were made with different thicknesses while bulk density was maintained at $141414 \mathrm{~kg} \mathrm{~m}^{-3}$ (bulk density with the best sound absorption coefficient from previous experiments). For the same bulk density, the measurement result shows that the sound absorption coefficient at lower frequencies increases along with an increase of sample thickness. The samples with $30 \mathrm{~mm}$ thick show a good sound absorption coefficient $(>0.8)$ and it was achieved at frequencies above $2000 \mathrm{~Hz}$. This is a special characteristic of porous absorber which has good sound absorption at high frequencies. The increasing sample thickness causes an improvement in sound absorption coefficient below $1250 \mathrm{~Hz}$.

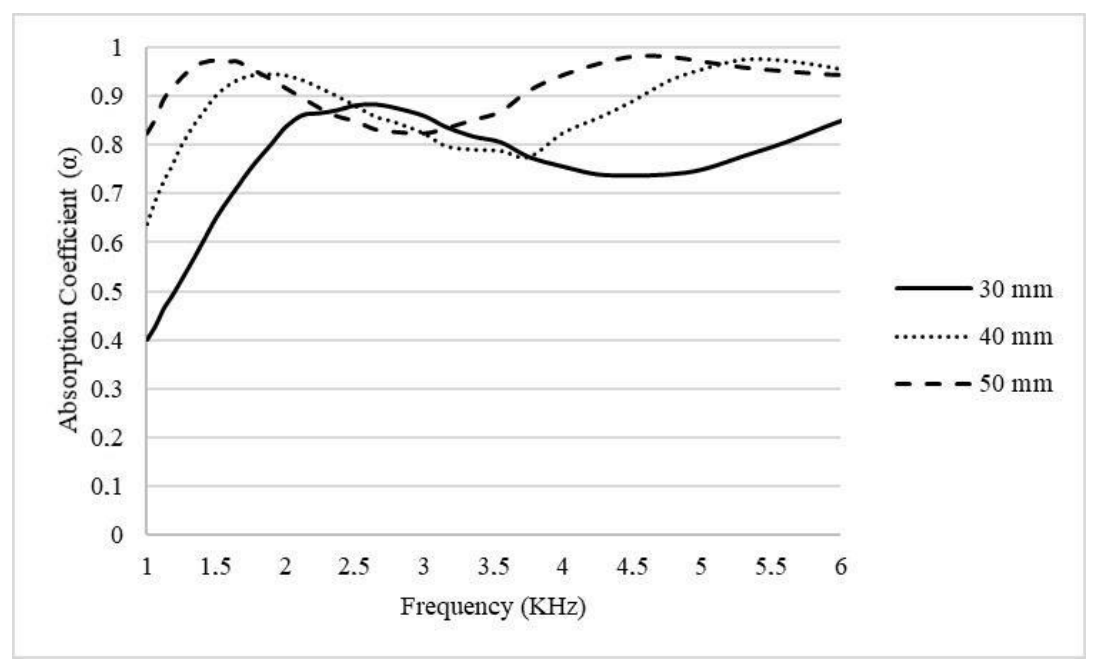

Fig. 4. Sound absorption coefficient of SPT fibers with different thicknesses, $t$ with constant bulk density, $\rho_{\text {bulk }}=141414 \mathrm{~kg} \mathrm{~m}^{-3}$.

\subsection{Effect of air gap}

This research also investigated the effect of adding an air gap applied behind the sample. The configuration of the sample in the impedance tube is illustrated in Figure 5. The sound absorption coefficient was measured using four different air gap configurations, i.e., $d=0$ $\mathrm{mm}, 10 \mathrm{~mm}, 20 \mathrm{~mm}$, and $30 \mathrm{~mm}$. The application of an air gap is intended to shift the peak toward a lower frequency. However, the sound absorption coefficient above the peak frequency has decreased slightly due to the formation of peaks and dips caused by standing waves in the air gap behind the sample $[18,27]$. The decline phenomenon can be seen in Figure 6.

In order to obtain good sound absorption coefficients at lower frequencies, the application of air gap is more efficient than using full-thickness absorbers. Application of the air gap can reduce the use of fiber so that the production costs can be reduced. As shown in Figure 7. sample with a thickness of $30 \mathrm{~mm}$ added with $10 \mathrm{~mm}$ air gap thickness indicates a sound absorption capability similar to a full thickness sample of $40 \mathrm{~mm}$ in the (1 000 to 2500$) \mathrm{Hz}$ frequency range. 


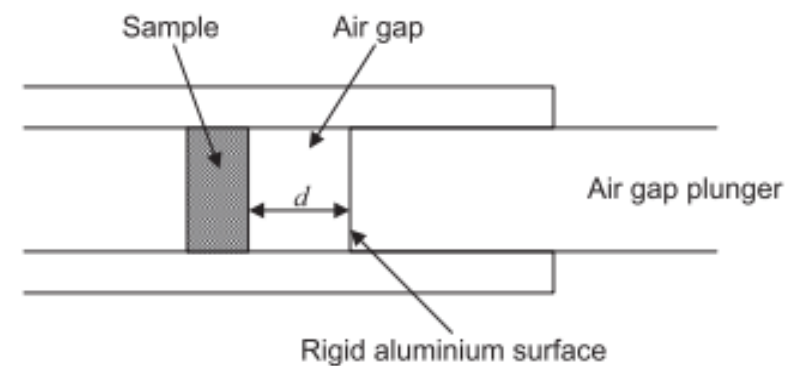

Fig. 5. Setup for air gap behind the sample.

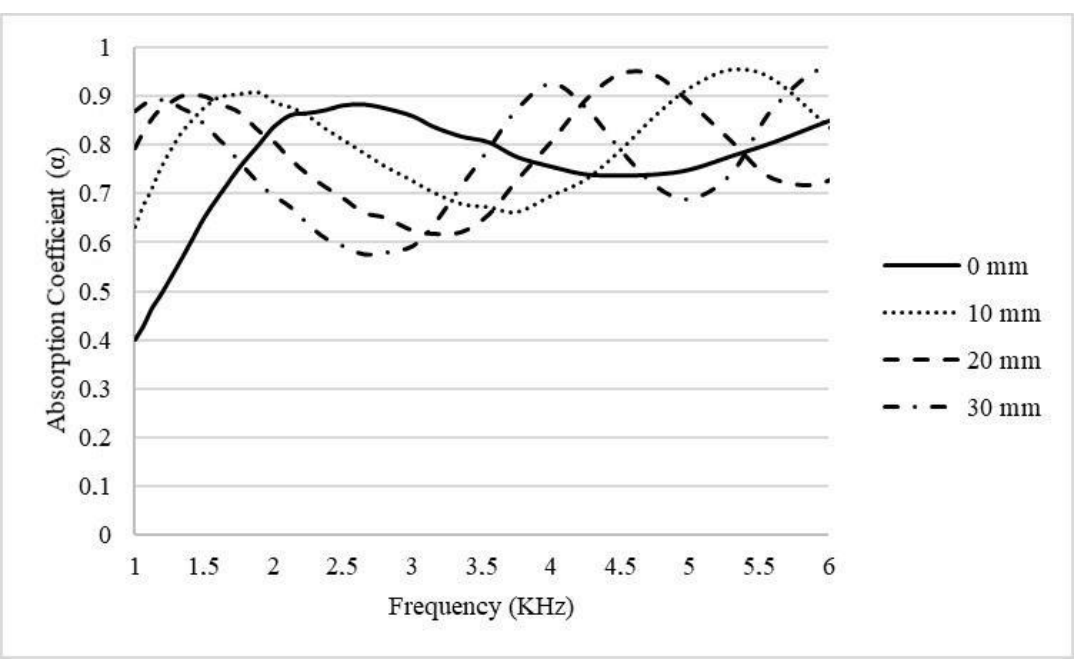

Fig. 6. The sound absorption coefficient of SPT fibers with a different air gap, $d$ with constant thickness, $\mathrm{t}=30 \mathrm{~mm}$ and bulk density, $\rho$ bulk $=141414 \mathrm{~kg} \mathrm{~m}^{-3}$.

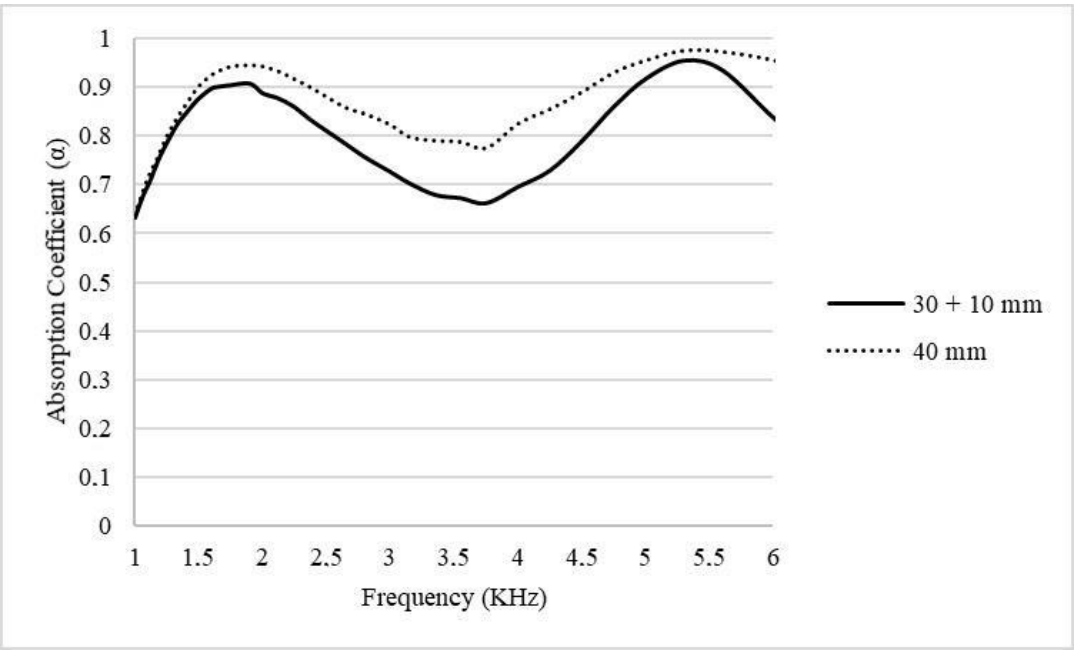

Fig. 7. Comparison of sound absorption coefficient between sample with a thickness of $t=40 \mathrm{~mm}$ without air gap and $\mathrm{t}=30 \mathrm{~mm}$ with air gap thickness of $\mathrm{d}=10 \mathrm{~mm}$ at the same SPT fiber bulk density of $141414 \mathrm{~kg} \mathrm{~m}^{-3}$. 


\section{Conclusion}

Sound absorption performance has been investigated in this experiment. From the experiment, samples with bulk density $141414 \mathrm{~kg} \mathrm{~m}^{-3}$ have the optimum sound absorption coefficient on $30 \mathrm{~mm}$ thick sample with a value above 0.7 at a frequency above $1600 \mathrm{~Hz}$. This research also showed that samples with $50 \mathrm{~mm}$ thickness had the optimum sound absorption performance compared to samples with lower thickness with values above 0.8 at a frequency of $1000 \mathrm{~Hz}$ and above. Furthermore, the sound absorption coefficient reaches 0.9 at (1 200 to 2000$) \mathrm{Hz}$ range of frequency. Good sound absorbing performance at lower frequencies can also be achieved by applying the gap behind the sample. The use of air gap allows fiber usage reduction compared to full thickness samples in the same total space.

The author would thank the Ministry of Research, Technology and Higher Education, The Republic of Indonesia, especially the Directorate General of Research and Development Strengthening for support of research and publication financial by a scheme of Post Graduate Research Grant (Hibah Tim Pascasarjana) 2018 (0045/E3/LL/2018, 16 Januari 2018, No.4497, Kuncoro Diharjo, Universitas 11 Maret, skema PTP).

\section{References}

1. M. Basner, W. Babisch, A. Davis, M. Brink, C. Clack, S. Janssen, S. Stansfeld, The Lancet, 383,9925:1325-1332(2014).

https://www.ncbi.nlm.nih.gov/pmc/articles/PMC3988259/

2. T.D. Rossing. Springer handbook of acoustics. 2nd ed. Heidelberg, New York: Springer (2014). https://www.springer.com/gp/book/9781493907540

3. J.P. Arenas, M.J. Crocker, Sound \& Vibration, 44,7:12-17(2010). http://www.sandv.com/downloads/1007croc.pdf

4. H.F. Xiang, D. Wang, H.C. Liua, N. Zhao, J. Xu, Chinese J. Polym. Sci., 31,3:521529(2013). https://link.springer.com/article/10.1007/s10118-013-1241-8

5. D.V. Parikh, Y. Chen, L. Sun, Text. Res. J., 76,11:813-820(2006). https://pubag.nal.usda.gov/pubag/downloadPDF.xhtml?id=14594\&content=PDF

6. N. Jiang, J.Y. Chen, D.V. Parikh, Bioresour. Technol., 100,24:6533-6536(2009). https://pubag.nal.usda.gov/download/37975/PDF

7. A. Putra, Y. Abdullah, H. Efendy, W.M. Farid, M.R. Ayob, M.S. Py, Procedia Eng., 53:632-638(2013). https://www.sciencedirect.com/science/article/pii/S1877705813002002

8. A. Ashori, Bioresour. Technol., 99,11:4661-4667(2008). https://www.researchgate.net/profile/Alireza_Ashori/publication/5780696 Woodplastic composites as promising greencomposites for automotive industries Review Paper/links/5a324aca458515afb690c2 93/Wood-plastic-composites-as-promising-green-composites-for-automotiveindustries-Review-Paper.pdf

9. S. Ersoy, H. Küçük, Appl. Acoust., 70,1:215-220(2009). https://www.sciencedirect.com/science/article/abs/pii/S0003682X0700196X

10. H. Yang, D. Kim, Y. Lee, H. Kim, J. Jeon, C. Kang, Bioresour. Technol., 95,1:6165(2004). https://www.sciencedirect.com/science/article/pii/S0960852404000446

11. A. Putra, Y. Abdullah, H. Efendy, W.M.F.W. Mohamad, N.L. Salleh, Adv. Acoust. Vib., 2013:1-7(2013). http://downloads.hindawi.com/journals/aav/2013/605932.pdf 
12. V. Tarnow, J. Acoust. Soc. Am., 105,1:234-240(1999).

http://orbit.dtu.dk/files/5393908/Tarnow.pdf

13. H.F. Xiang, S.X. Tan, X.L. Yu, Y.H. Long, X.L. Zhang, N. Zhao, et al., Chinese J. Polym. Sci., 29,6:650-657(2011). https://link.springer.com/article/10.1007/s10118011-1079-X

14. K. Kosuge, A. Takayasu, T. Hori, J. Mater. Sci., 40,20:5399-5405(2005). https://link.springer.com/article/10.1007/s10853-005-4338-9

15. F. Asdrubali, Survey on the acoustical properties of new sustainable materials for noise control, Paper presented in Euronoise (Tempere, Finland, 2006). http://www.ciriaf.it/ft/File/Pubblicazioni/pdf/1279.pdf

16. F. Asdrubali, S. Schiavoni, K.V. Horoshenkov, Build. Acoust., 19,4:283-311(2012). https://journals.sagepub.com/doi/abs/10.1260/1351-010X.19.4.283

17. World Health Organization (WHO), Air quality guidelines for Europe, 2nd ed. Copenhagen: World Health Organization Regional Office for Europe (2000). https://wedocs.unep.org/bitstream/handle/20.500.11822/8681/Air_quality_guidelines.p df? sequence=3

18. Z.Y. Lim, A. Putra, M.J.M. Nor, M. Y. Yaakob, Appl. Acoust., 130:107-114(2018). https://www.sciencedirect.com/science/article/abs/pii/S0003682X17305583

19. K.H. Or, A. Putra, M.Z. Selamat, Appl. Acoust., 119:9-16(2017). https:/www.sciencedirect.com/science/article/abs/pii/S0003682X16305412

20. A. Putra, K.H. Or, M.Z. Selamat, M.J.M. Nor, M.H. Hassan, I. Prasetiyo, Appl. Acoust., 136:9-15(2018).

https://www.sciencedirect.com/science/article/pii/S0003682X17310708

21. N.T. Rahmawati, J. Prodi Biol., 6,8:447-454(2017). [in Bahasa Indonesia] http://journal.student.uny.ac.id/ojs/index.php/biologi/article/download/7882/7508

22. D.A. Herawati, L. Wijayanti, Produksi Glukosa dari Limbah Padat Industri Pati Aren Menggunakan Trichoderma sp., [Glucose production from solid waste Aren starch industrial using Trichoderma sp.], paper presented in Seminar Nasional Teknologi Kimia, Industri dan Informasi, (Makassar, Indonesia, 2015). [in Bahasa Indonesia] http://docplayer.info/39546086-Produksi-glukosa-dari-limbah-padat-industri-pati-arenmenggunakan-trichoderma-sp.html

23. M.B.N. Rahman, B. Riyanta, K. Diharjo, J. Ilm. Semesta Tek., 14,1:26-32(2011). [in Bahasa Indonesia] http://journal.umy.ac.id/index.php/st/article/download/567/713

24. Wijoyo, A. Nurhidayat, Kajian Ketangguhan Impak Komposit Sandwich Serat ArenPolyester dengan Core Gedebog Pohon Pisang, [Toughness study of composite impact of Aren-polyester fiber sandwich with banana tree Gedebog Core], Simposium Nasional RAPI XII, (Surakarta, Indonesia, 2013), Proceedings Simposium Nasional ke-12 RAPI 2013 12:111-116. [in Bahasa Indonesia] https://publikasiilmiah.ums.ac.id/bitstream/handle/11617/4035/M18 TM30_2_Wijoyo UNSA.pdf? sequence $=1 \&$ isAllowed $=y$

25. E. Pamungkas, M.R.A. Cahyono, Y. Prisusatyo, Y.I. Yuraida, Y.T. Karunawardani, 'Briquette La Bendo', Pemanfaatan Limbah Ampas Onggok Menjadi Bisnis Briket sebagai Pemberdayaan Masyarakat Dusun Bendo Desa Daleman Kecamatan Tulung Kabupaten Klaten, ['Briquette La Bendo', Utilization of Onggok dregs waste into a briquette business as community empowerment in Dusun Bendo, Daleman Village, Tulung District, Klaten Regency] (Makassar, Indonesia, 2013), e-Proceeding PIMNAS 2013. [in Bahasa Indonesia] https://media.neliti.com/media/publications/170101-IDbriquette-la-bendo-pemanfaatan-limbah-am.pdf 
26. M. Firdayati, M. Handajani, Jurnal Infrastruktur dan Lingkungan Binaan, 1,2:2229(2015). [in Bahasa Indonesia]

https://www.researchgate.net/profile/Marisa_Handajani/publication/266584054_J_u_r n_a 1_Studi_Karakteristik_Dasar_Limbah_Industri_Tepung_Aren_1/links/54c90c7b0c

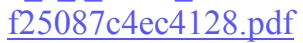

27. L.Z. Ying, A. Putra, M.J.M. Nor, N. Muhammad, Sound Absorption of Multilayer Natural Coir and Kenaf fibers, paper presented in The 23rd International Congress of Sound and Vibration, (Athens, Greece, 2016).

https://ukm.pure.elsevier.com/en/publications/sound-absorption-of-multilayer-naturalcoir-and-kenaf-fibers 